\title{
Selective cytotoxic and anti-metastatic activity in DU-145 prostate cancer cells induced by Annona muricata L. bark extract and phytochemical, annonacin
}

Kimberley Foster ${ }^{1,2}$, Omolola Oyenihi ${ }^{3}$, Sunelle Rademan ${ }^{3}$, Joseph Erhabor ${ }^{3}$, Motlalepula Matsabisa ${ }^{3}$, James Barker ${ }^{4}$, Moses K. Langat ${ }^{5}$, Amy Kendal-Smith ${ }^{5,6}$, Helen Asemota ${ }^{2}$ and Rupika Delgoda ${ }^{1 *}$ (D)

\begin{abstract}
Background: Annona muricata L. was identified as a popular medicinal plant in treatment regimens among cancer patients in Jamaica by a previously conducted structured questionnaire. Ethnomedically used plant parts, were examined in this study against human prostate cancer cells for the first time and mechanisms of action elucidated for the most potent of them, along with the active phytochemical, annonacin.

Methods: Nine extracts of varying polarity from the leaves and bark of $A$. muricata were assessed initially for cytotoxicity using the MTT (3-(4,5-dimethylthiazol-2-yl)-2,5-diphenyltetrazolium bromide) assay on PC-3 prostate cancer cells and the ethyl acetate bark (EAB) extract was identified as the most potent. EAB extract was then standardized for annonacin content using High-performance Liquid Chromatography - Mass Spectrometry (HPLCMS) and shown to be effective against a second prostate cancer cell line (DU-145) also. The mode of cell death in DU-145 cells were assessed via several apoptotic assays including induction of increased reactive oxygen species (ROS) production, reduction of mitochondrial membrane potential, activation of caspases and annexin $\mathrm{V}$ externalization combined with morphological observations using confocal microscopy. In addition, the potential to prevent metastasis was examined via inhibition of cell migration, vascular endothelial growth factor (VEGF) and angiogenesis using the chorioallantoic membrane assay (CAM).

Results: Annonacin and EAB extract displayed selective and potent cytotoxicity against the DU-145 prostate carcinoma cells with $\mathrm{IC}_{50}$ values of $0.1 \pm 0.07 \mu \mathrm{M}$ and $55.501 \pm 0.55 \mu \mathrm{g} / \mathrm{mL}$ respectively, without impacting RWPE-1 normal prostate cells, in stark contrast to chemotherapeutic docetaxel which lacked such selectivity. Docetaxel's impact on the cancerous DU-145 was improved by 50\% when used in combination with EAB extract. Insignificant levels of intracellular ROS content, depolarization of mitochondrial membrane, Caspase 3/7 activation, annexin V content, along with stained morphological evaluations, pointed to a non-apoptotic mode of cell death. The extract at $50 \mathrm{\mu g} / \mathrm{mL}$ deterred cell migration in the wound-healing assay, while inhibition of angiogenesis was displayed in the CAM and VEGF inhibition assays for both EAB $(100 \mu \mathrm{g} / \mathrm{mL})$ and annonacin $(0.5 \mu \mathrm{M})$.

(Continued on next page)
\end{abstract}

\footnotetext{
* Correspondence: thejani.delgoda@uwimona.edu.jm

${ }^{1}$ Natural Products Institute, University of the West Indies, Mona, Kingston 7 , Jamaica

Full list of author information is available at the end of the article
}

(c) The Author(s). 2020 Open Access This article is licensed under a Creative Commons Attribution 4.0 International License, which permits use, sharing, adaptation, distribution and reproduction in any medium or format, as long as you give appropriate credit to the original author(s) and the source, provide a link to the Creative Commons licence, and indicate if changes were made. The images or other third party material in this article are included in the article's Creative Commons licence, unless indicated otherwise in a credit line to the material. If material is not included in the article's Creative Commons licence and your intended use is not permitted by statutory regulation or exceeds the permitted use, you will need to obtain permission directly from the copyright holder. To view a copy of this licence, visit http://creativecommons.org/licenses/by/4.0/ The Creative Commons Public Domain Dedication waiver (http://creativecommons.org/publicdomain/zero/1.0/) applies to the data made available in this article, unless otherwise stated in a credit line to the data. 
(Continued from previous page)

Conclusions: Taken together, the standardized EAB extract and annonacin appear to induce selective and potent cell death via a necrotic pathway in DU-145 cells, while also preventing cell migration and angiogenesis, which warrant further examinations for mechanistic insights and validity in-vivo.

Keywords: ROS, Caspase, Prostate cancer, Annonacin, Ethnopharmacology, Antiangiogenesis, Docetaxel, Annona muricata L

\section{Background}

Small molecular secondary metabolites found expressed in plants have played a key, adaptive role aiding in their evolution from single cellular organisms coping in a harsh chemical soup, to being multicellular, terrestrial organisms, equipped to gain reproductive vantages or vade off overgrazers and diseases [1]. These vastly diverse group of small molecules that provide the plant with such advantages other than their primary functions of respirations, have inspired man-kind to experiment on plants over millennia for solutions to their own health problems. Thus, the high reliance on plant remedies by over $80 \%$ of the developing world for primary care [2], similar to the $73 \%$ self-medicating rates with herbs in Jamaica [3], provide evidence for the strong belief in the healing properties resident in plants. The development mean of approximately $32 \%$ of pharmaceuticals and botanical mixtures derived directly from or inspired by natural products over the past 39 years [4] for the treatment or prevention of multiple health issues including cancer, diabetes and microbial infections, provide credence to such beliefs.

Unsurprisingly plants have been utilized in the management of cancer since time immemorial in many traditional medical systems and remain a major source for bioprospecting [5], having inspired over $50 \%$ of cancer drugs approved over the past four decades [4], including vincristine, vinblastine, paclitaxel, camptothecin and podophyllotoxin [6]. Jamaica has a wide array of selfmedicated herbs and medicinal plants in use against illnesses [7], with some displaying anti-cancer properties. Petiveria alliacea and key phytochemical, dibenzyl trisulfide [8] and the Jamaican ball moss (Tillandsia recurvata L.) [9] exemplifies use in prostate cancer, among other biodiversity with disparate cytotoxic properties [10]. A recent survey among cancer patients in the country [11] helped identify common ethnomedical practices in the island nation and Annona muricata L. emerged as a popular ingredient, in line with findings emerging from Indonesia, [12] and Trinidad [13].

Comprehensive ethnobotanical studies of the Annonaceae family have been conducted in recent years [14] and the therapeutic potential of Annona muricata, the most prominent species of the Annonaceae family examined in the treatment of insomnia, rheumatism, hypertension and various cancers [15]. Reports have emerged from Nigeria [16], Mexico [17] and the Philippines [15] for the therapeutic application of a decoction of the leaves to treat cancers of the prostate and stomach among others, while in Peru [18], infusions of the leaves are used for cancer treatment [15]. Evaluating these reports highlight the fact that although leaf preparations have undergone some scrutiny, bark extracts have remained largely unexplored.

The two major classes of phytochemicals found in $A$. muricata are flavonoids and acetogenins both of which are associated with a plethora of pharmacological activities individually or synergistically in a wide array of plants [19-21]. Annonacin commonly occurs in various species of the Annonaceae family and is the major acetogenin of A. muricata [22]. Multiple studies have demonstrated its ability to exert anti-tumor effects against endometrial, breast and skin cancer through cell cycle arrest and other cell signaling pathways [23-25]. There is mounting evidence to support the antitumor activity through apoptosis induction in numerous cancer cell lines such as colon and breast cancer [5]. This, along with cell cycle arrest at G1 phase are some of the well reported antitumor mechanisms of A. muricata leaf [26-30]. Though, many studies have shown mitochondrial mediated apoptosis, cell death can occur independently of mitochondrial involvement without the generation of Reactive Oxygen Species (ROS) to trigger apoptosis, and full evaluations are required in each type of cancer cell.

In this study we evaluated, the cytotoxic value of polar and non-polar leaf and bark extracts of $A$. muricata, the two most popularly used plant parts in ethnomedicine [11] on prostate cancer cells. With the aid of a panel of biochemical monitors, we demonstrate the usefulness of the most potent of those extracts, along with the key phytochemical annonacin, alone and in combination therapy with a standard chemotherapeutic drug, docetaxel. Their impact on prostate cells was independent of ROS, caspases activity and appeared to follow a necrotic pathway of cytotoxicity. Demonstrating strong anti-angiogenetic properties these natural products warrant future in-depth scrutiny on in-vivo prostate cancer models. 


\section{Methods}

\section{Plant material}

Aerial parts (leaf and bark) of Annona muricata were collected in August 2017 from the Botanical Gardens at the University of the West Indies (U.W.I), Mona, Jamaica. A. muricata, which grows wildly in Jamaica is not an endangered species, hence no special governmental permission was required for collection. Voucher specimens were deposited at the Herbarium in the Department of Life Sciences, U.W.I., Mona with Accession Numbers 36,362 and 36,363, following authentication by herbarium curator, Mr. Patrick Lewis.

\section{Preparation of extracts}

The leaves and bark of $A$. muricata were collected, cleaned, dried at room temperature and pulverized into powder. $5 \mathrm{~g}$ of leaf and bark separately or $2.5 \mathrm{~g}$ leaf and $2.5 \mathrm{~g}$ bark combined were then sequentially extracted with hexane, ethyl acetate and ethanol (200 mL each) for 3 days at room temperature. Three extracts per solvent (hexane, ethyl acetate and ethanol) were prepared using the leaf, bark and leaf:bark combination in a 1:1 ratio totaling nine extracts of varying polarity. The resulting suspension from solvent extract was filtered through type 2 Whatman filter paper and the filtrate evaporated to dryness using a rotary evaporator at low temperature [28]. The extracts obtained from each solvent were weighed, labeled and stored at $-20^{\circ} \mathrm{C}$ in sealed tubes until further use.

\section{Cell culture}

PC-3 and DU-145 human prostate carcinoma cells and RWPE-1 normal prostate epithelial cells obtained from American Type Cell Collection (ATCC, Manassas, VA, USA) were used for the cytotoxicity determination in the study. PC-3 cells were maintained in Kaighn's modification of Ham's F-12 medium (F-12 K) and DU-145 cells were maintained in ATCC formulated Eagle's Minimum Essential Medium (EMEM) supplemented with $10 \%$ fetal bovine serum (FBS) while RWPE-1 cells were maintained in Keratinocyte Serum Free Medium supplemented with human recombinant epidermal growth factor and bovine pituitary extract. All cell lines were incubated in a humidified atmosphere with 5\% carbon dioxide in the air at $37{ }^{\circ} \mathrm{C}$ until $90 \%$ confluence after which they were harvested for the viability experiments.

\section{Cell viability assay}

The MTT assay (3-(4,5-dimethylthiazol-2-yl)-2,5-diphenyltetrazolium bromide) was used to evaluate cell viability. An optimized cell concentration 15,000 cells/well were seeded in 96-well plates and incubated for 24h. Cells were subsequently treated with extracts, annonacin, docetaxel and a combination of EAB extract and docetaxel at different concentrations ranging from 50 to $100 \mu \mathrm{g} / \mathrm{mL}$ extract and $0.0001-0.0016 \mu \mathrm{g} / \mathrm{mL}$ for docetaxel and incubated for $72 \mathrm{~h}$, after which the MTT solution was added and incubated for another $4 \mathrm{~h}$ at $37^{\circ} \mathrm{C}$. The medium was aspirated and the crystals formed solubilized with the addition of $100 \mu \mathrm{L}$ dimethyl sulfoxide (DMSO) to each well. Finally, the resulting absorbance was measured at $570 \mathrm{~nm}$ using a microplate reader and the percentage of cell viability calculated as a ratio of untreated cells in vehicle control (1\% DMSO). The experiments were performed in triplicate and the results expressed as the mean \pm standard error of the mean $[31,32]$.

\section{Standardization of extract using HPLC-MS}

$5.7 \mathrm{mg}$ of the ethyl acetate extract was dissolved in $57 \mu \mathrm{L}$ methanol and analyzed by HPLC-MS (Velos-Pro, Thermo Fisher Scientific); Phenomenex C18 column: $150 \times 3 \mathrm{~mm}, 3 \mu \mathrm{m}$ particle size (method:0-1 $\mathrm{min}=$ isocratic gradient $10 \%$ methonol, $90 \% \mathrm{H}_{2} \mathrm{O} ; 1-18 \mathrm{~min}=$ linear gradient $30 \%$ methanol, $70 \% \mathrm{H}_{2} \mathrm{O}$ to $78 \%$ methanol, $22 \% \mathrm{H}_{2} \mathrm{O} ; 18-20 \mathrm{~min}=78 \%$ methanol, $22 \% \mathrm{H}_{2} \mathrm{O}$ to $100 \%$ methanol) alongside standard of pure annonacin. Concentrations were estimated from the peak area of the corresponding molecular ion peak $\left([\mathrm{M}+\mathrm{H}]^{+} ; \mathrm{m} / \mathrm{z}\right.$ 597.60) in positive electron spray ionization mode, using known concentrations of annonacin standard for calibration, and accounting for dilution in $80 \%$ methanol [33]. ${ }^{1} \mathrm{H}$ NMR spectrum of pure annonacin was analyzed using a $400 \mathrm{MHz}$ NMR Avance spectrophotometer to authenticate it.

\section{Reactive oxygen species assay}

The generation of reactive oxygen species (ROS) is often associated with chemotherapeutic and other nonsurgical interventions in cancer, as a means of triggering cell death. Often the intracellular generation of ROS is indicative of early induction of apoptosis [34]. Since ROS generations were previously observed for $A$. muricata leaf and twig extracts in HL-60 leukemia cells [35], we evaluated such potential by EAB extract and annonacin on DU-145 cells. Intracellular ROS generation was determined using the single reagent $2^{\prime}, 7^{\prime}-$ dichlorofluorescein diacetate (DCFDA). This is a cell permeant, fluorogenic dye which can be oxidized to DFC $\left(2^{\prime}, 7^{\prime}-\right.$ dichlorofluorescein $)$ as the fluorescent product, detected by a spectrofluorometer used to measure hydroxyl, peroxyl and other reactive oxygen species (ROS) activity within the cell [35]. DU-145 cells were treated with the EAB extract, annonacin and $2.5 \mu \mathrm{M}$ hydrogen peroxide $\left(\mathrm{H}_{2} \mathrm{O}_{2}\right)$ as positive control for $72 \mathrm{~h}$. After incubation, the media was removed, cells were washed with Phosphate-buffered saline (PBS) then stained with $100 \mu \mathrm{L}$ DCFDA and incubated for another 
30 mins in the dark at $37^{\circ} \mathrm{C}$. After which the fluorescence intensity was subsequently measured at $485 \mathrm{~nm}$ excitation and $535 \mathrm{~nm}$ emission using a microplate reader.

\section{Mitochondrial membrane potential using the JC-10 assay} The mitochondria play an important role in apoptosis detection and induction of cell death [36]. The change in mitochondrial membrane potential (MMP) was measured using the JC-10 assay kit (Sigma-Aldrich, USA) according to vendor's instructions. This uses a dual emission fluorescent dye capable of entering the mitochondria and emits either red or green fluorescence depending on the state of the mitochondrial membrane. Red fluorescence is seen in normal polarized mitochondria while a green fluorescence is obtained when the mitochondrial membrane potential decreases and the membrane is depolarized causing the dye to diffuse into the cytoplasm of the cell. Treated DU-145 cells (with docetaxel, varying concentrations of $\mathrm{EAB}$, annonacin, control and $10 \mu \mathrm{M}$ of $\mathrm{H}_{2} \mathrm{O}_{2}$ ) were incubated in 96-well plates for $72 \mathrm{~h}$. After incubation, the media was removed, cells were washed with PBS then stained with $50 \mu \mathrm{L} /$ well of the JC-10 dye loading solution. The plate was then incubated for 50 mins in a $37{ }^{\circ} \mathrm{C}$ incubator protected from light after which $50 \mu \mathrm{L} /$ well of assay buffer B was added, then fluorescence intensity subsequently read at excitation/emission wavelengths of $490 / 525 \mathrm{~nm}$ and $540 / 590 \mathrm{~nm}$ [37]. Results are recorded as a ratio of red to green fluorescence.

\section{Human Annexin V assay}

During apoptosis, the cell membrane is altered and Phosphatydylserine (PS) located in the membrane leaflets become exposed at the cell surface and allow for binding of annexin V. Total annexin V in treated DU145 prostate cancer cells was quantitatively measured with the Human annexin $\mathrm{V}$ Platinum ELISA kit (Affymetrix, eBioscience, Vienna, Austria) by comparing to the standard provided in kit following the vendor's kit manual. Briefly, $50 \mu \mathrm{L}$ of treated cell supernatant in triplicates was used for annexin $\mathrm{V}$ determination. The assay was conducted at room temperature and results monitored at $620 \mathrm{~nm}$ [38].

\section{Caspase $3 / 7$ assay}

Manufactures' instructions were followed for CellEvent ${ }^{\circ}$ Caspase-3/7 Green reagent allowing detection of Caspase 3 activity. Briefly, treated DU-145 cells were incubated for $24 \mathrm{~h}$ with $0.6 \mu \mathrm{g} / \mathrm{mL}$ annonacin, (50 and $100 \mu \mathrm{g} / \mathrm{mL}) \mathrm{EAB}$ extract and $10 \mu \mathrm{M}$ of $\mathrm{H}_{2} \mathrm{O}_{2}$ as positive control in 96-well plates at a concentration of 15,000 cells/well. After incubation $4 \mu \mathrm{M}$ Caspase-3/7 Green Detection Reagent was added to each well and incubated for $30 \mathrm{mins}$. The results were analyzed by a fluorescence microplate reader at $503 \mathrm{~nm} / 530 \mathrm{~nm}$ excitation/emission $[39,40]$.

\section{Ethidium bromide and Acridine Orange staining}

Cells were seeded into 6-well plates lined with coverslips at a concentration of 250,000 cells/well. Confluent cells were treated with various concentrations of extract and compound and incubated for $72 \mathrm{~h}$. After incubation, the cells were subsequently washed with PBS and then treated with a dye mixture containing ethidium bromide and acridine orange $(1: 1,100 \mu \mathrm{g} /$ $\mathrm{mL}$ ) for $15 \mathrm{~min}$ covered with foil. After 15 mins the stain was removed, and the cells rinsed with PBS. 1 $\mathrm{ml}$ of paraformaldehyde was added to the cells for 15 mins to fix the stained cells on the coverslips. After removing the paraformaldehyde, the coverslips were removed and mounted on slides viewed under confocal microscopy [41].

\section{Cell migration assay}

The more metastatic prostate cancer cell line (PC-3) was used to assess the anti-metastatic potential of the EAB extract. PC-3 cells were seeded into 6-well plates at a concentration of 250,000 cells/well. Confluent cells were scratched using a sterile $200-\mu \mathrm{l}$ pipette tip and washed twice with PBS to remove detached cells. The image of cells in each well was captured at time $0 \mathrm{~h}$. Cells were treated with various concentrations of extract and incubated for $24 \mathrm{~h}$ at $37^{\circ} \mathrm{C}$ with $5 \%$ carbon dioxide in the atmosphere. After incubation, cells were washed with PBS to remove cell debris $[28,42]$. Images were subsequently captured after incubation using an Amscope digital eyepiece microscope camera attached to an inverted microscope. Data was statistically analysed using GraphPad software, and results were expressed as percentage cell migration.

\section{Chicken chorioallantoic membrane - CAM assay}

Three eggs per sample (in triplicates) were obtained from a local hatchery in Bloemfontein, South Africa and incubated for 8 days at $37^{\circ} \mathrm{C}$ with $60 \%$ humidity. Egg shells were sterilized with $70 \%$ ethanol and a 1 $\mathrm{cm}^{2}$ window on the air space end was cut opened on the 8th day to expose the blood vessels. A $1 \mathrm{~cm}^{2}$ sterile Whatman filter paper shocked with the compound, extract, Tinzaparin (positive control) and L-arginine (negative control) was placed on the surface of the growing CAM vessels. The eggs were then labelled and re-sealed with sterile adhesive tape in a laminar flow hood and incubated for another 3 days. On day 11, the CAMs were reopened in sterile petri dishes, photographed and blood vessels in each CAM were 

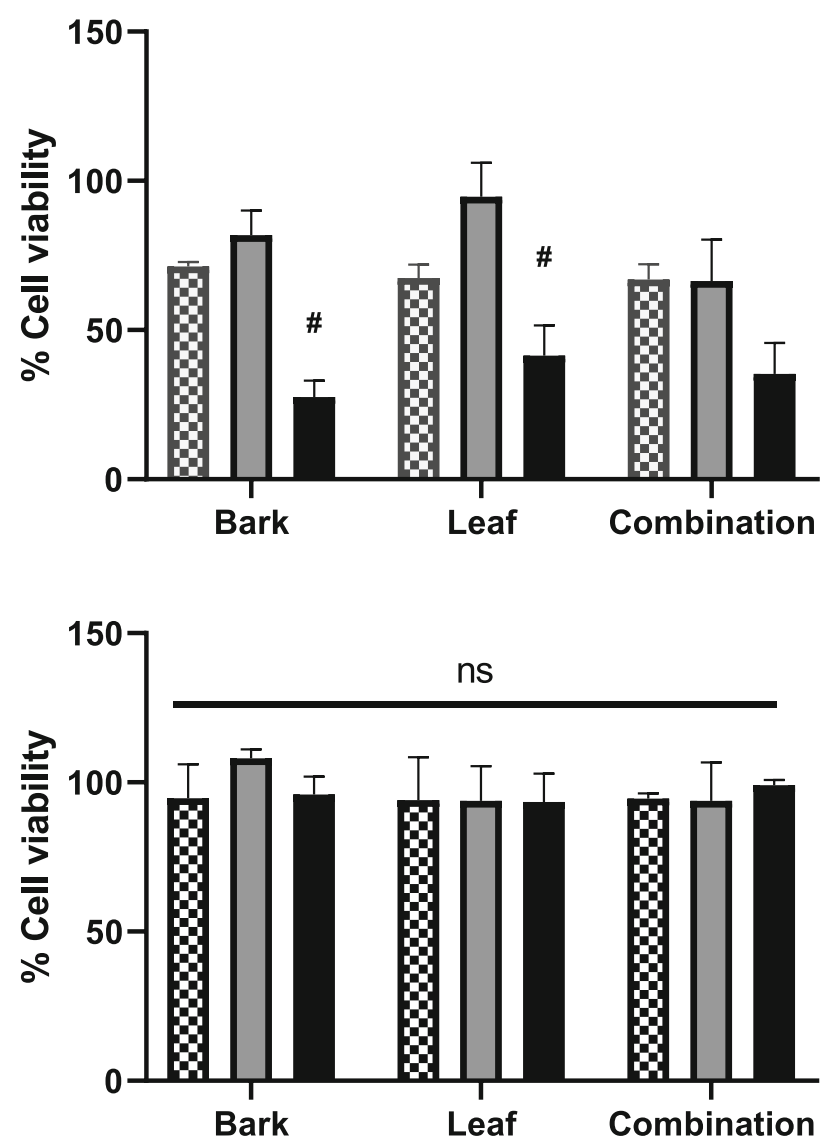

(A)

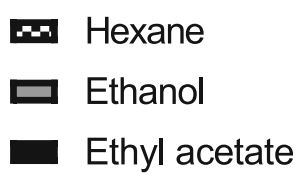

(B)

Fig. 1 A. muricata L. leaf and bark extracts display selective anti-proliferative activity on prostate cancer cells. PC-3 prostate cancer cell line (a) and RWPE-1 normal prostate cell line (b) were treated for $72 \mathrm{~h}$ with $100 \mu \mathrm{g} / \mathrm{mL}$ extracts of hexane, ethanol and ethyl acetate of leaf, bark alone and leaf:bark in 1:1 ratio. Cell viability was calculated as a percentage of solvent control (1\% each solvent as control for each type of extract) and results are represented as mean \pm SEM $(n=3)$. For different extracts with the same plant part, \# represents statistically significant differences $(p<$ 0.05 , two-way ANOVA). 'ns' represents no statistical significance

counted. The results were presented as the angiogenic index for each sample $[43,44]$.

\section{VEGF inhibition assay}

The extracellular vascular endothelial growth factor (VEGF) levels were assayed using the supernatant of earlier treated DU-145 cells [43]. The cells were seeded in a 48-well plate at a concentration of 50,000 cells per well. To influence the cell growth and VEGF production, $0.01 \mathrm{mg} / \mathrm{ml}$ of insulin was supplemented in the culture medium. After $24 \mathrm{~h}$ incubation, cells were treated with extract and test compound and incubated for $72 \mathrm{~h}$ after which plates were centrifuged at $5000 \mathrm{~g}$ for $10 \mathrm{~min}$ and the supernatant collected for VEGF estimation. Total VEGF content in cultured supernatants was estimated following the instructions of Human VEGF ELISA kit (ThermoFisher Scientific).

\section{Statistical analysis}

The results were expressed as the mean \pm standard errors of the mean. Assays were conducted in three individual experiments, each performed in triplicates. $\mathrm{IC}_{50}$ values were determined using nonlinear regression analysis on Sigma Plot (version 10.0) software. All other statistical analyses were performed with GraphPad Prism 8.0 (USA). The overall effects of plant part, solvent type and the interaction of both on cell viability were determined using two-way ANOVA followed by Tukey's multiple comparisons test to check for significant differences between the data. One-way analysis of variance (ANOVA) followed by Tukey's multiple comparisons post hoc test was used to compare treated cells with the control. Significant differences were reported with $* *$ indicating a $p$-value $<0.0001, * *$ indicating a $p$-value $<0.001$ and *indicating a $p$-value $<0.05$. 


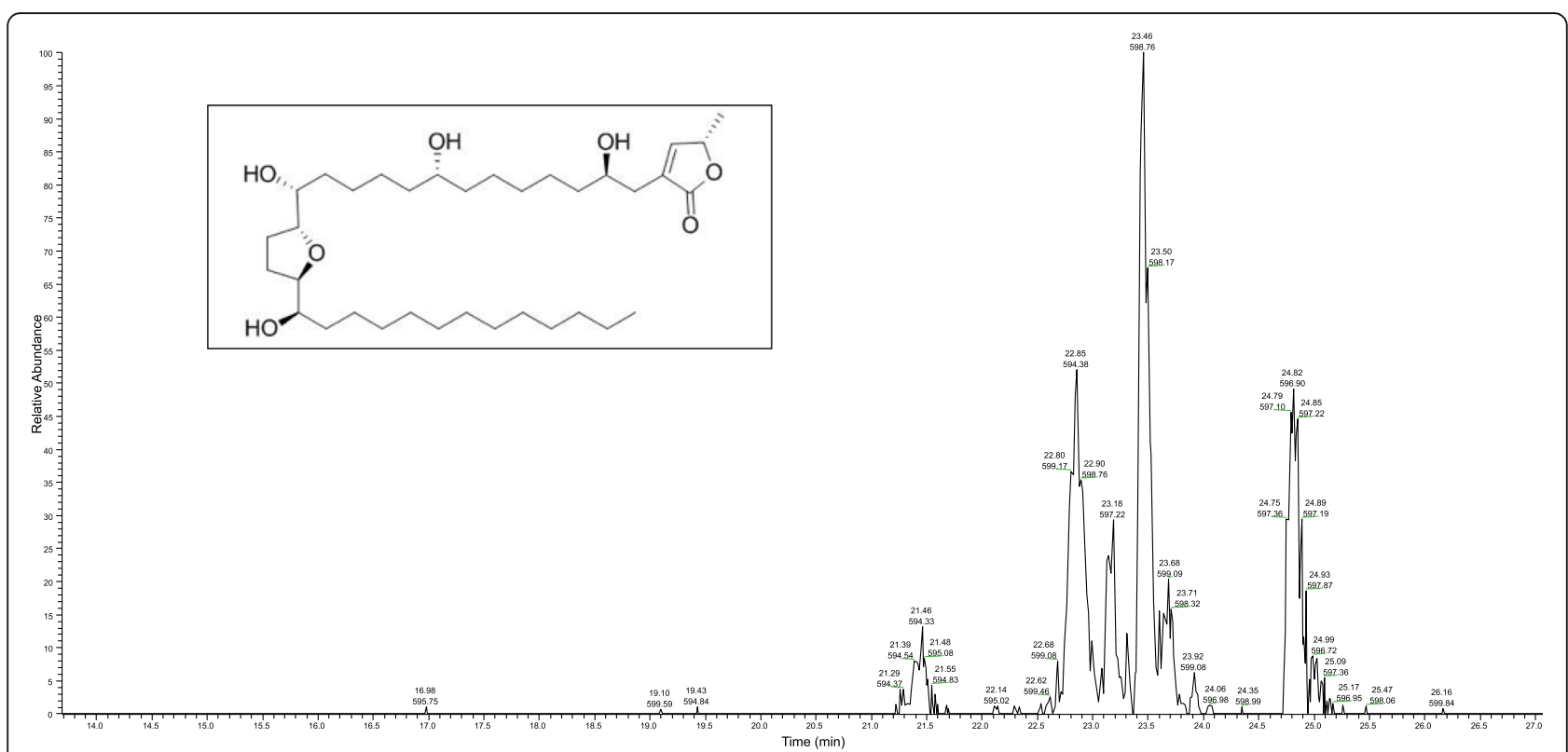

Fig. 2 HPLC-MS chromatogram of the standardized EAB extract showing annonacin. Filtered positive mode output (597.5 (+/- 1.5) from Velos pro representing the annonacin (inset) abundance in bark of Annona muricata. Annonacin is identified at $23.18 \mathrm{~min}$

\section{Results}

Selective cytotoxic effect of $A$. muricata extracts on PC-3 prostate cancer cells and RWPE-1 normal prostate cells Nine extracts of varying polarity including three extracts per solvent (hexane, ethyl acetate and ethanol) prepared using the leaf, bark and leaf:bark combination in a 1:1 ratio were analyzed for their cytotoxic potential. This experiment utilized the most commonly used parts of the plant in ethnomedical practices. All such extracts prepared were subsequently screened at a concentration of $100 \mu \mathrm{g} / \mathrm{mL}$ against cancerous (PC-3) and normal (RWPE-1) prostate cell lines and results depicted in Fig. 1. Inducing the largest impact (30\% cell viability) on the cancerous PC-3 cells, the ethyl acetate extract of the bark was identified as the most potent and selective, with negligible impact ( $>90 \%$ cell viability) on the normal cells. It is noteworthy that all examined extracts of this plant elicited low cytotoxicity on normal cells.

\section{Standardization of ethyl acetate bark extract}

Having identified the ethyl acetate extract of the bark $(E A B)$ as the most potent, the presence of the key phytochemical, annonacin, was identified and quantified in this extract using HPLC-MS (Fig. 2). The level of annonacin was $<100 \mathrm{ppm}$ when compared to its standard. After filtering for a molecular weight of $597.5(+/-1.5)$ in positive mode, accounting for the added ion to annonacin molecular weight, and compared to the standard it was determined that annonacin is identifiable with a retention time, leaving the column at, $23.18 \mathrm{~min}$ with a molecular weight of 597.60 .

\section{Improved cytotoxicity of chemotherapeutic drug,} docetaxel in combination with standardized EAB extract

To ensure that the observed cytotoxicity with PC3 in Fig. 1 was not cell line dependent, we examined the effect of EAB extract and annonacin on DU-145 cells also, a cell line derived from brain metastasis of human prostate cancer $[45,46]$. Dose dependent inhibitions of the growth of DU-145 were observed after $72 \mathrm{~h}$ incubations (Fig. 3) and the $\mathrm{IC}_{50}$ values obtained for the extract $(55.5 \pm 0.55 \mu \mathrm{g} / \mathrm{mL})$ and annonacin $(0.079 \pm 0.07 \mu \mathrm{g} / \mathrm{mL}$ or $0.1 \mu \mathrm{M})$, were compared to that of docetaxel $\left(0.0004 \pm 1.59 \times 10^{-5} \mu \mathrm{g} / \mathrm{mL}\right.$ or $\left.0.05 \mathrm{nM}\right)$, a standard chemotherapeutic drug as shown in Table 1. Combining docetaxel with EAB extract induced an even greater impact on cell viability (Fig. $3 \mathrm{~d}$ ), reducing the $\mathrm{IC}_{50}$ of the former to $0.0002 \mu \mathrm{g} / \mathrm{mL}$ within a $95 \%$ confidence interval. A likely synergistic interaction underlies this improvement of docetaxel impact in the presence of the extract and we recommend future studies for a full understanding of this hypothesis. Having observed that the EAB extract is effective in reducing the cell viability of a second type of prostate cancer cell line, we undertook further work on the extract to gain mechanistic insights using DU-145 cells. Since DU145 models a moderately metastatic prostate cancer as opposed to grade IV adenocarcinoma PC3 cells with high metastatic potential, we selected the DU145 cell line for mechanistic study with suitability for studying treatment interventions in the early stages. 

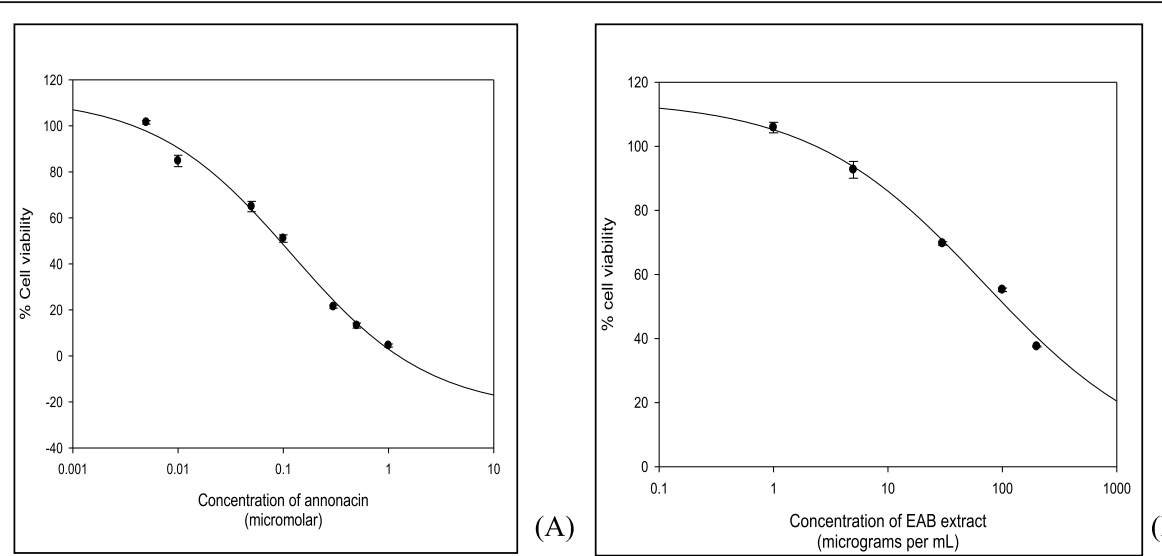

(B)
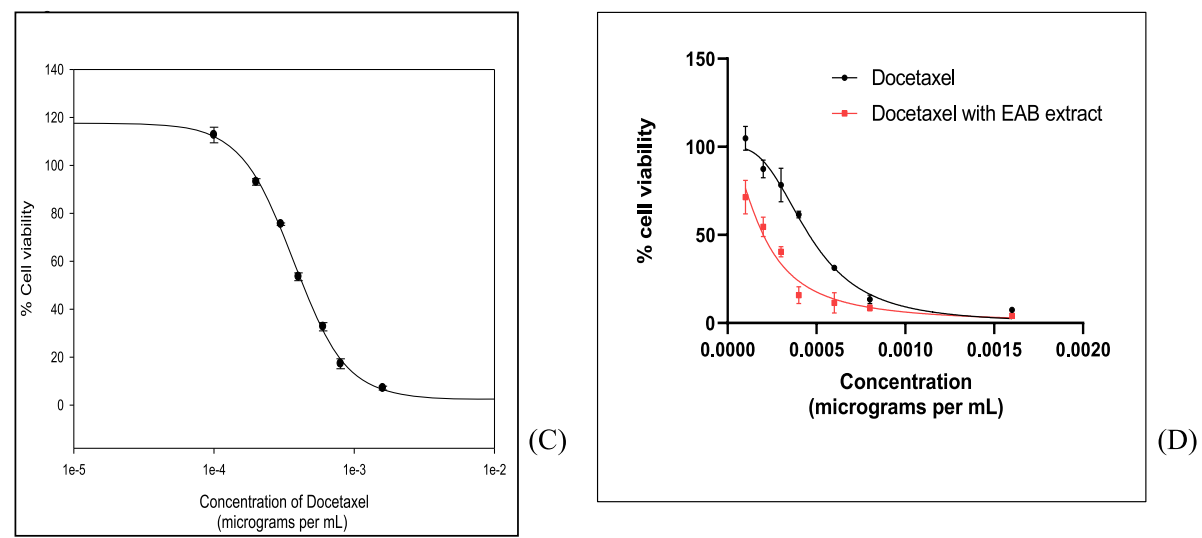

Fig. $3 E A B$ extract and annonacin display dose dependent impact on cell viability of DU-145 cells. Antiproliferative activity of (a) annonacin, (b) ethyl acetate extract of $A$. muricata bark (EAB), (c) docetaxel and (d) docetaxel in combination with $100 \mathrm{\mu g} / \mathrm{ml}$ EAB extract against DU-145 prostate cancer cells determined by MTT assay after $72 \mathrm{~h}$ incubation with varying concentrations of each sample. Results are means \pm SEM of triplicates in three independent experiments and the percentage of cell viability was calculated as a percentage of solvent control (1\% DMSO). A dose dependent decrease in cell viability was observed with all test samples and combining docetaxel with the EAB extract reduced the observed $\mathrm{IC}_{50}$

Additionally, PC3 is suspect of carrying co-regulators for tumor suppression, which could complicate mechanistic studies, weighing into our decision to work with DU145 cells for this study.

\section{EAB extract and annonacin does not elicit ROS generation} in DU-145 cells

Our results using the fluorogenic probe, 2, 7dichlorofluorescin diacetate $\left(\mathrm{H}_{2} \mathrm{DCFDA}\right)$ which oxidizes to its highly fluorescent form dichlorofluorescein (DCF)

Table $1 I_{50}$ values for the extract, annonacin and docetaxel on cancerous DU-145 cells and normal RWPE-1 cells, after $72 \mathrm{~h}$

\begin{tabular}{lll}
\hline Treatment & \multicolumn{1}{l}{ Cell lines, $\mathbf{I} \mathbf{C}_{\mathbf{5 0}}$ value $(\boldsymbol{\mu g} / \mathbf{m L})$} & \\
\cline { 2 - 3 } & DU-145 & RWPE-1 \\
\hline EAB extract & $55.501 \pm 0.55$ & $>0.48$ \\
Annonacin & $0.0793 \pm 0.07$ & $0.0004^{a}$ \\
Docetaxel & $0.0004 \pm 1.59$ &
\end{tabular}

Results are expressed as mean \pm SEM of three independent experiments. ${ }^{a}-I_{50}$ value obtained from Karanika et al. [47] in the presence of ROS, indicate that neither the $A$. muricata extract nor annonacin triggered significant increases in levels of intracellular ROS in prostate cancer cells. When compared to the untreated control, there was no difference in the percent ROS obtained as shown in Fig. 4 , in contrast to a $2.5 \mu \mathrm{M}$ solution of hydrogen peroxide which elicited a three-fold increase in oxidative capacity, while $10 \mu \mathrm{M}$ hydrogen peroxide elicited a nineteen fold increase (data not displayed).

\section{Measurement of mitochondrial membrane potential by JC-10 assay}

Cells treated with annonacin and EAB extract displayed a ratio comparative to the control healthy cells, indicating that the cytotoxic effect of $A$. muricata bark extract in prostate cancer cell does not involve the depolarization of mitochondrial membrane (Fig. 5). In contrast, docetaxel (known to impart anti-cancer activity via apoptotic pathway) displayed significantly lower ratio of healthy red cells in comparison to the damaged green cells $(69 \%$, red:green 


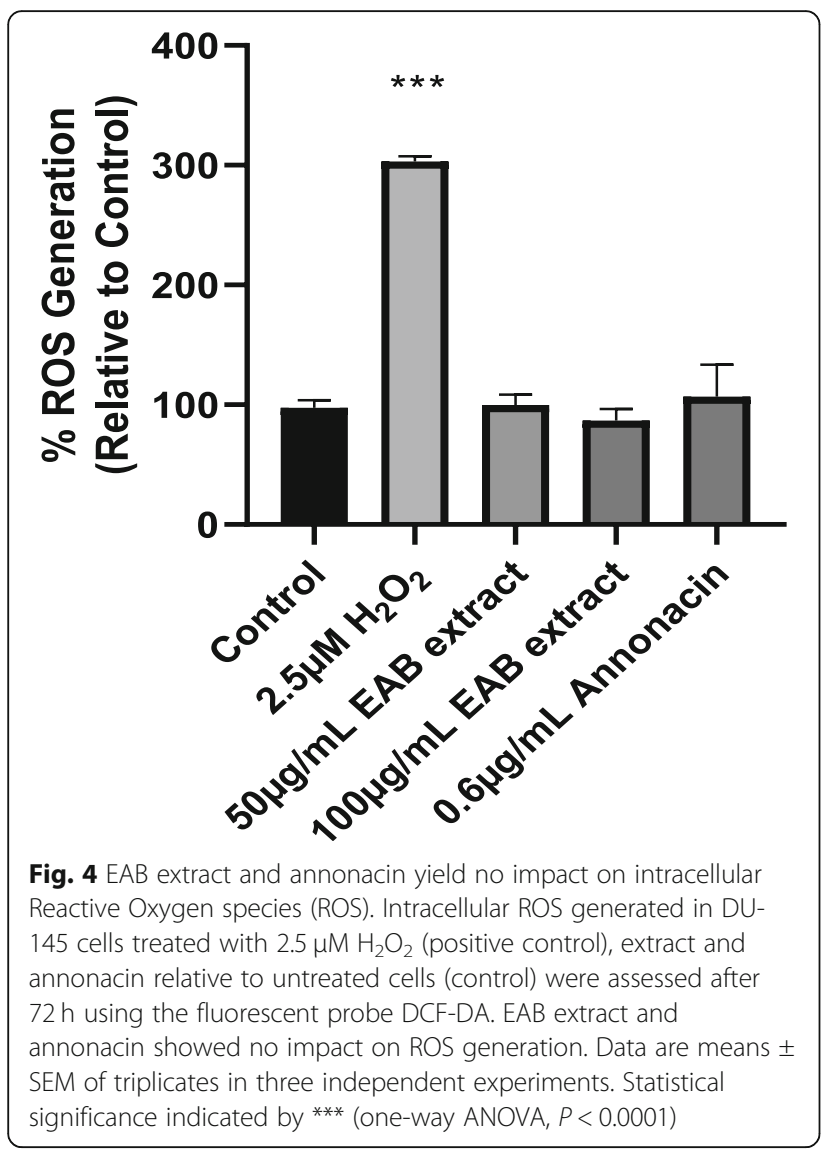

ratio) in comparison to the untreated cells. Similarly, a $10 \mu \mathrm{M}$ solution of hydrogen peroxide solution was able to depolarize the mitochondrial membrane resulting in a significantly reduced (35\%) healthy cell content ratio in comparison to the control.

\section{Human Annexin V externalization confirms lowered apoptotic body formation}

To further confirm the absence of an apoptotic pathway, the levels of annexin $\mathrm{V}$ present in the cell membrane of treated DU-145 prostate cancer cells were quantitatively determined using the Human annexin V ELISA kit and compared to the provided standard, annexin V in buffered protein base. Results indicate that treated DU-145 cells displayed low levels of annexin $\mathrm{V}$ when treated with annonacin as evident in Fig. 6, with anomalous behavior at $30 \mu \mathrm{g} / \mathrm{mL}$ and $50 \mu \mathrm{g} / \mathrm{mL}$. However, statistical analysis showed there was no significant difference between all tested concentrations in comparison to the control. Whether there is some combination of apoptotic bodies being formed at these low concentrations followed by other forms of cell death, remains to be fully explored, but certainly the Fig. 6 indicates that between the range

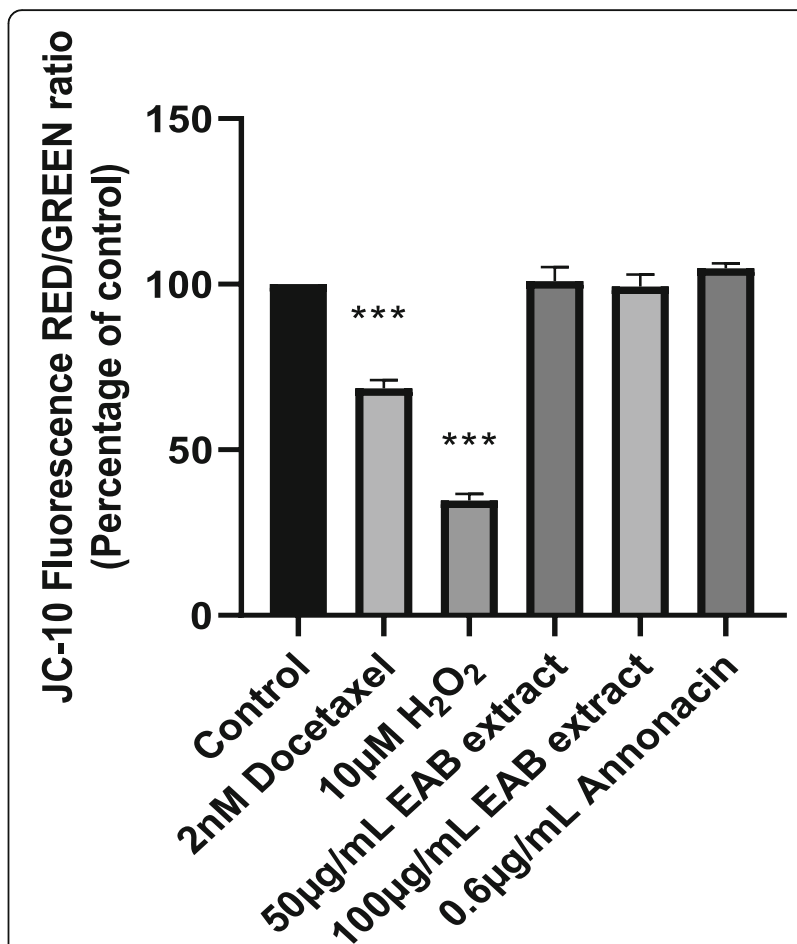

Fig. $5 \mathrm{EAB}$ extract and annonacin does not alter the mitochondrial membrane potential (MMP) in DU-145 cells. Quantitative evaluation of the effects of annonacin and EAB extract on MMP in DU-145 cells after $72 \mathrm{~h}$ was carried out using JC-10 Fluorescence dye computed relative to untreated cells (control). Cell were treated with $10 \mu \mathrm{M}$ $\mathrm{H}_{2} \mathrm{O}_{2}$ and $2 \mathrm{nM}$ docetaxel as positive control as docetaxel disrupts MMP. EAB extract and annonacin displayed healthy cell content of near $100 \%$ similar to the control, while those treated with docetaxel yielded 69\% healthy cell and hydrogen peroxide displayed 39\% healthy cell ratio, as measured by the healthy (red) cell count in comparison to the damaged (green) cells. . Data are means \pm SEM of triplicates in three independent experiments. Statistical significance indicated by *** (one-way ANOVA, $P<0.0001$ )

of $10-200 \mu \mathrm{g} / \mathrm{mL}$ annexin V levels stayed fairly uniform. Similarly, the levels of annexin $\mathrm{V}$ detected when cells were treated with annonacin is uniformly low as well.

\section{Measurement of Caspase-3/7 activity}

The activation of caspase- 3 and caspase- 7 which are major players in the caspase cascade signaling apoptotic cell death were evaluated to further characterize the cytotoxicity induced by EAB and annonacin. As seen in Fig. 7, neither annonacin nor the ethyl acetate extract of A. muricata bark increased caspase-3/7 activity when compared to untreated cells, suggesting a caspase independent cell death. On the other hand, an increase in caspase-3/7 activation was observed in cells treated with a $10 \mu \mathrm{M}$ solution of hydrogen peroxide - a widely used apoptosis inducer [48]. 


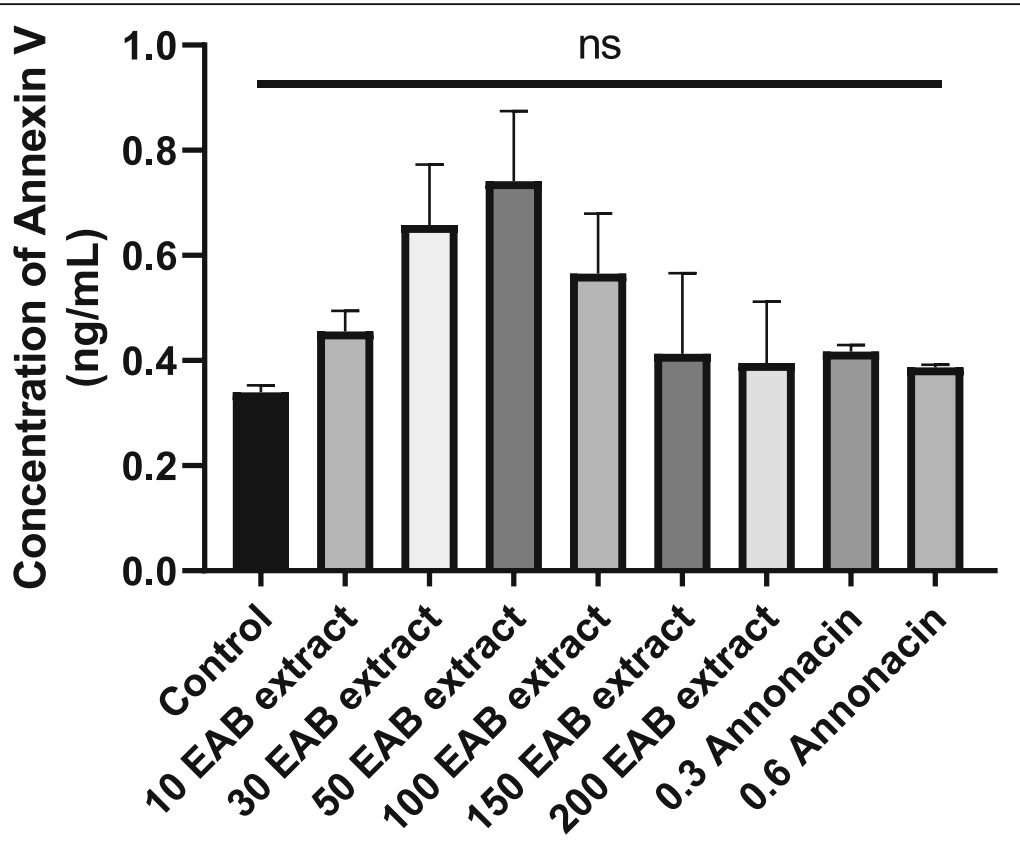

\section{Treatment Concentration (micrograms $/ \mathrm{mL}$ )}

Fig. 6 EAB extract and annonacin generates low annexin $V$ content. Figure displays the concentrations of annexin $V$ detected in DU-145 cells treated with varying concentrations of EAB extract and annonacin for $72 \mathrm{~h}$ calculated based on the standard curve generated. Data are expressed as means \pm SEM of triplicate values and no statistically significant differences (indicated by ' $n s$ ') were observed from corresponding controls (oneway ANOVA), albeit the somewhat varying patterns displayed

\section{Acridine Orange/ Ethidium bromide staining confirm morphological changes}

The images obtained after double staining treated cells with acridine orange and ethidium bromide following a 72-h exposure to EAB extract and annonacin revealed morphological changes which permits qualitative detections of modes of cell death. In Fig. 8 cells in the control group appeared normal on confocal microscopy images exhibiting bright green fluorescence signals from the nuclei, suggesting the uptake of acridine orange stain [49]. In the treatment groups, majority of the cells emitted orange to red fluorescence signaling the uptake of ethidium bromide stain through damaged cell membranes. The nuclei of the cells were also characteristically uniform depicting necrotic pathway, as they did not display visible apoptotic characteristics such as fragmentation of the nuclei or formation of apoptotic bodies.

\section{Inhibitory effect of EAB extract on the migration of prostate cancer cells}

In order to assess A muricata's effect on endothelial cell migration, a visual depiction was garnered using an invitro wound healing assay on highly metastatic PC-3 prostate cancer cells as shown in Fig. 9. Both $50 \mu \mathrm{g} / \mathrm{ml}$ and $100 \mu \mathrm{g} / \mathrm{ml}$ of EAB extracts maintained a significant clearing of the denuded area created by the scratch on the monolayer of cells, in comparison to the ethyl acetate (solvent) treated and untreated controls after $24 \mathrm{~h}$. Treatment yielded less than $20 \%$ of cell migration rates compared to the control groups seen to promote wound healing and cell migration for return of cell-cell contact.

Quantification of angiogenic index induced by annonacin and EAB extract via the CAM assay

Further evaluations on the $A$. muricata extract on angiogenesis and tumor invasion was garnered by an assessment using the highly vascularized CAM assay. The $\mathrm{EAB}$ extract at $60 \mu \mathrm{g} / \mathrm{ml}$ and $100 \mu \mathrm{g} / \mathrm{ml}$ inhibited the formation of new blood vessels in the CAM with an angiogenic index of 35 and 23 respectively when compared to the negative control L-Arginine, angiogenic index 53. The suppression of angiogenesis shown by the compound annonacin was similar to that observed for the positive control tinzaparin (angiogenic index, 14). Annonacin at $7 \mu \mathrm{g} / \mathrm{ml}(11.7 \mu \mathrm{M})$ had the lowest angiogenic index of 19 amongst the tested samples when compared to the positive control Tinzaparin as well as the negative control L-Arginine as represented in Fig. 10 which shows less defined capillaries in images 3-5 similar to image 2 (positive control) in comparison to image 1 with 


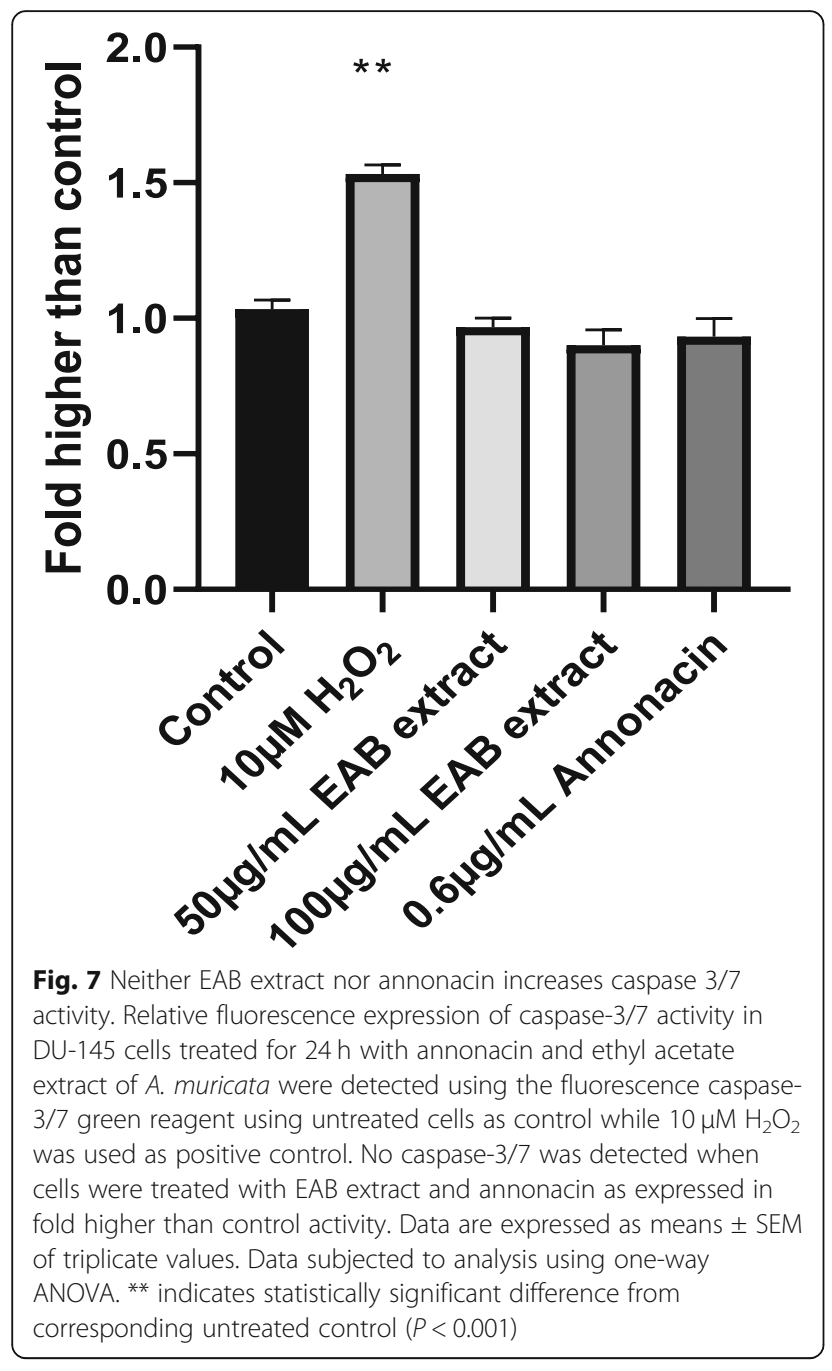

Fig. 7 Neither EAB extract nor annonacin increases caspase 3/7 activity. Relative fluorescence expression of caspase-3/7 activity in DU-145 cells treated for $24 \mathrm{~h}$ with annonacin and ethyl acetate was used as positive control. No caspase-3/7 was detected when of triplicate values. Data subjected to analysis using one-way corresponding untreated control $(P<0.001)$ well-developed capillaries. These results highlight their antiangiogenic potential which might prove beneficial in preventing cancer metastasis.

\section{VEGF inhibition induced by annonacin and EAB extract}

To further evaluate the impact on angiogenesis, effect on a potent angiogenetic factor, Vascular endothelial growth factor (VEGF) elicited by the natural extracts were quantified. All tested concentrations of the EAB extract significantly reduced the levels of VEGF in the cell in comparison to the control. However, $200 \mu \mathrm{g} / \mathrm{mL}$ of the extract, had the highest inhibition against the extracellular VEGF level and was significantly lower when compared between the groups (Fig. 11). Annonacin at a concentration of $0.6 \mu \mathrm{g} / \mathrm{mL}(1 \mu \mathrm{M})$ was also found to reduce extracellular VEGF level when compared to the untreated control (media).

\section{Discussion}

Recognizing the value of ethnomedicine in the search for novel solutions, this investigation evaluated extracts of Annona muricata, which are employed by $52 \%$ of prostate cancer patients in Jamaica as home remedies [11], for impact against prostate cancer cells. The leaves and bark of this popular fruit tree are prepared as decoctions and infusions, and thus following evaluations of nine extracts of varying polarity, the ethyl acetate extract of the bark was deemed the most potent. It was therefore standardized for annonacin content and evaluated for impact on prostate cancerous and normal cells followed by likely mechanism inducing such impact.

A. muricata is reportedly one of the most commonly used plants as complementary and alternative treatment by cancer patients in various cultures $[11,13,50]$ and often used concomitantly with prescription medicines in patients undergoing chemotherapy [51, 52]. Interestingly, as Fig. 3 depicts, a possible synergistic interaction renders the $\mathrm{EAB}$ extract docetaxel combination

\section{(A)}

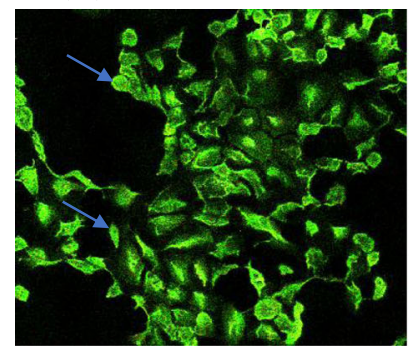

(B)

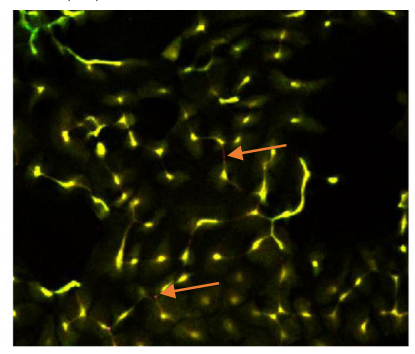

(C)

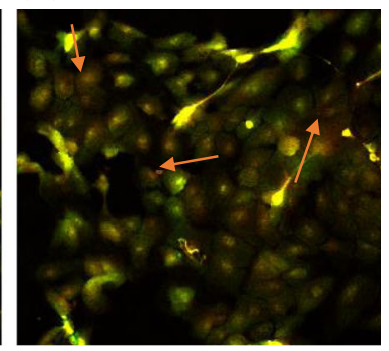

Fig. 8 Confocal microscopy images of acridine orange/ethidium bromide double stained DU-145 cells reveals necrotic pathway in the presence of EAB and annonacin treatment. Treatment with (b) $50 \mu \mathrm{g} / \mathrm{mL}$ EAB extract and (c) $0.6 \mu \mathrm{g} / \mathrm{mL}$ annonacin for $72 \mathrm{~h}$ compared to (a) untreated cells as control reveal necrotic cells (red in appearance, red arrow) in annonacin and EAB treatment groups, in comparison to viable healthy cells as stained uniformly green (blue arrow) in (A) in the control group. Magnification $10 \times$ 

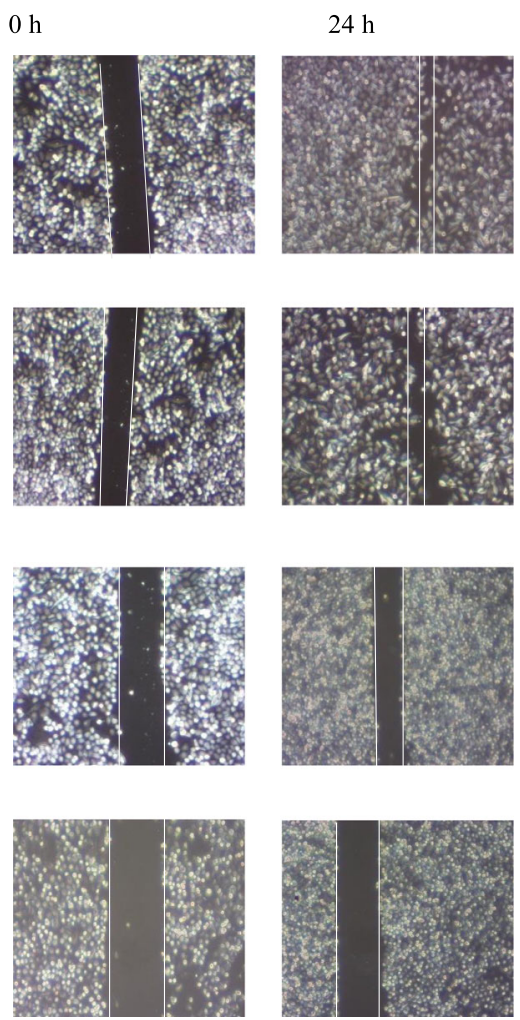

$24 \mathrm{~h}$

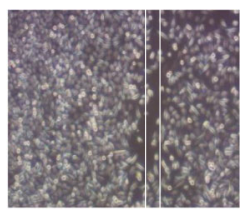

(A)

(B)

(C)

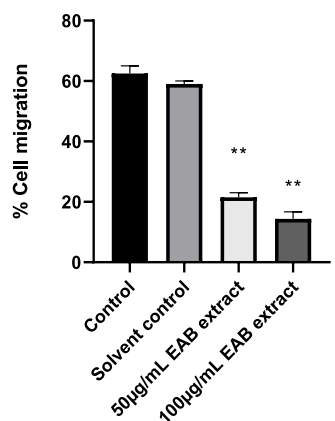

Fig. 9 EAB extract significantly reduces cell migration. $E A B$ extract at $100 \mu \mathrm{g} / \mathrm{ml}$ (d) and $50 \mu \mathrm{g} / \mathrm{ml}$ (c) inhibited migration of highly metastatic prostate cancer cells PC-3 cells compared to untreated control (a) and cells treated with solvent ethyl acetate (b). Cells were seeded into 6-well plates for $24 \mathrm{~h}$ after which each well was scratched at image captured at $0 \mathrm{~h}$, treated and incubated for another $24 \mathrm{~h}$ where images were subsequently captured to demonstrate the extent of migration. The maintenance of a larger denude (visually) in the EAB treated groups indicate the lowered levels of cell migration (quantitated). Statistical significance indicated by ** indicating a $p$-value $<0.001$ (one-way ANOVA)

significantly more effective than the pharmaceutical alone. Combined with the fact that annonacin and $A$. muricata extracts imparted highly selective cytotoxicity on cancerous cells in comparison to normal cells, stands it apart from pharmaceutical treatment alone. The potent $\mathrm{IC}_{50}$ value of $55 \mu \mathrm{g} / \mathrm{ml}$ for $\mathrm{EAB}$ extract against the cancerous cells dwarfs in comparison to its $\mathrm{IC}_{50}$ for the normal prostate cells $(>300 \mu \mathrm{g} / \mathrm{ml})$, similar to the 6 -fold increase in $\mathrm{IC}_{50}$ of annonacin on normal cells (Table 1), while the impact of docetaxel stands in stark contrast invoking comparable toxicity on both normal and cancerous cells [47].

Results garnered from Figs. 4 and 5 in this study, indicate that neither the extract nor annonacin induced cell death with an increasing ROS content or damage to the mitochondrial membrane. Cell deaths were observed without the activation of caspases (Fig. 7), a key requirement used to confirm the induction of apoptosis in cancer cells [53]. High doses of ROS can cause an irreversible loss of mitochondrial membrane potential in cells leading to the release of cytochrome $\mathrm{c}$ from the mitochondria and subsequent signaling of executioner caspases resulting in programmed cell death via apoptosis pathway [34, 54]. Most pathways of programmed cell death involve regulation by the mitochondria but there are instances where cell death is controlled in the plasma membrane by its many receptors responsible for death signaling such as tumor necrosis factor and Fas [55]. Studies have demonstrated the potential of $A$. muricata extract to inhibit TNF- $\alpha$ [56]. The results of the annexin $\mathrm{V}$ binding assay in Fig. 6 illustrates that there was some amount of phosphatidylserine exposure detected by increase in annexin V concentration around the $\mathrm{IC}_{50}$ which was not observed at higher concentrations of the extract. Although externalization of phosphatidylserine is characteristic of apoptotic cells, no significant increase in its content was observed and it has been shown where phosphatidylserine can be detected in early primary necrosis [57]. Other forms of programmed cell death include necrosis-like cell death characterized by the absence of both chromatin condensation and caspase activation [58].

Engagement of necrosis-like form of cell death was further suspected from the morphological observations using fluorescence microscopy following acridine orange/ethidium bromide staining (Fig. 8). Both 


\begin{tabular}{|c|c|c|}
\hline Image no. & $\begin{array}{l}\text { Sterile filter paper } \\
\text { shocked with } \\
\text { treatment solutions }\end{array}$ & $\begin{array}{l}\text { Angiogenic index } \\
\text { (No. of } \\
\text { capillaries) }\end{array}$ \\
\hline & $(\mu \mathrm{g} / \mathrm{ml})$ & \\
\hline 1 & $\begin{array}{c}10 \mathrm{~L}-\text { arginine } \\
\text { (negative control }\end{array}$ & 53 \\
\hline 2 & $\begin{array}{c}10 \text { Tinzaparin } \\
\text { (positive control) }\end{array}$ & 14 \\
\hline 3 & $60 \mathrm{EAB}$ extract & 35 \\
\hline 4 & 100 EAB extract & 23 \\
\hline 5 & 7 Annonacin & 19 \\
\hline
\end{tabular}

(A)
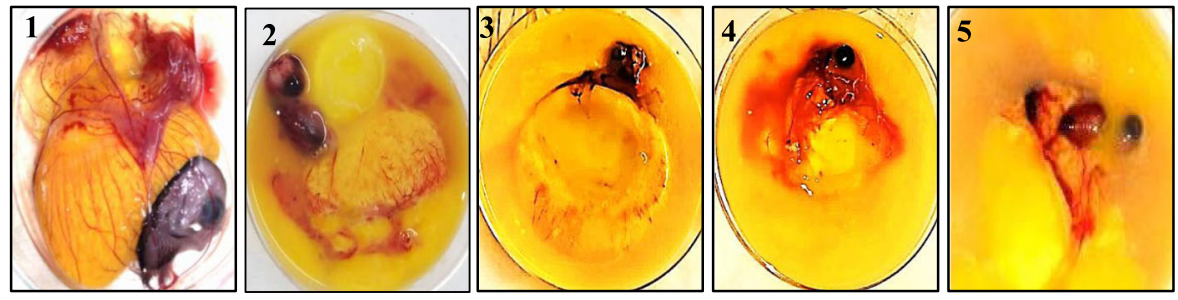

(B)

Fig. 10 Suppression of angiogenesis by EAB extract and annonacin. Representative results of the CAM assay displaying (a) angiogenic index obtained from each treatment and $(\mathbf{b})$ images of the treated eggs opened on day 11. The images represent the following treatments 1: LArginine, 2: Tinzaparin $(20 \mu \mathrm{g} / \mathrm{mL}), 3: E A B$ extract $(60 \mu \mathrm{g} / \mathrm{mL}), 4: E A B$ extract $(100 \mu \mathrm{g} / \mathrm{mL}), 5$ : Annonacin $(7 \mu \mathrm{g} / \mathrm{mL})$ and a summary of the angiogenic index obtained from each treatment. The results indicate a lowered angiogenesis potential in the presence of $E A B$ and annonacin

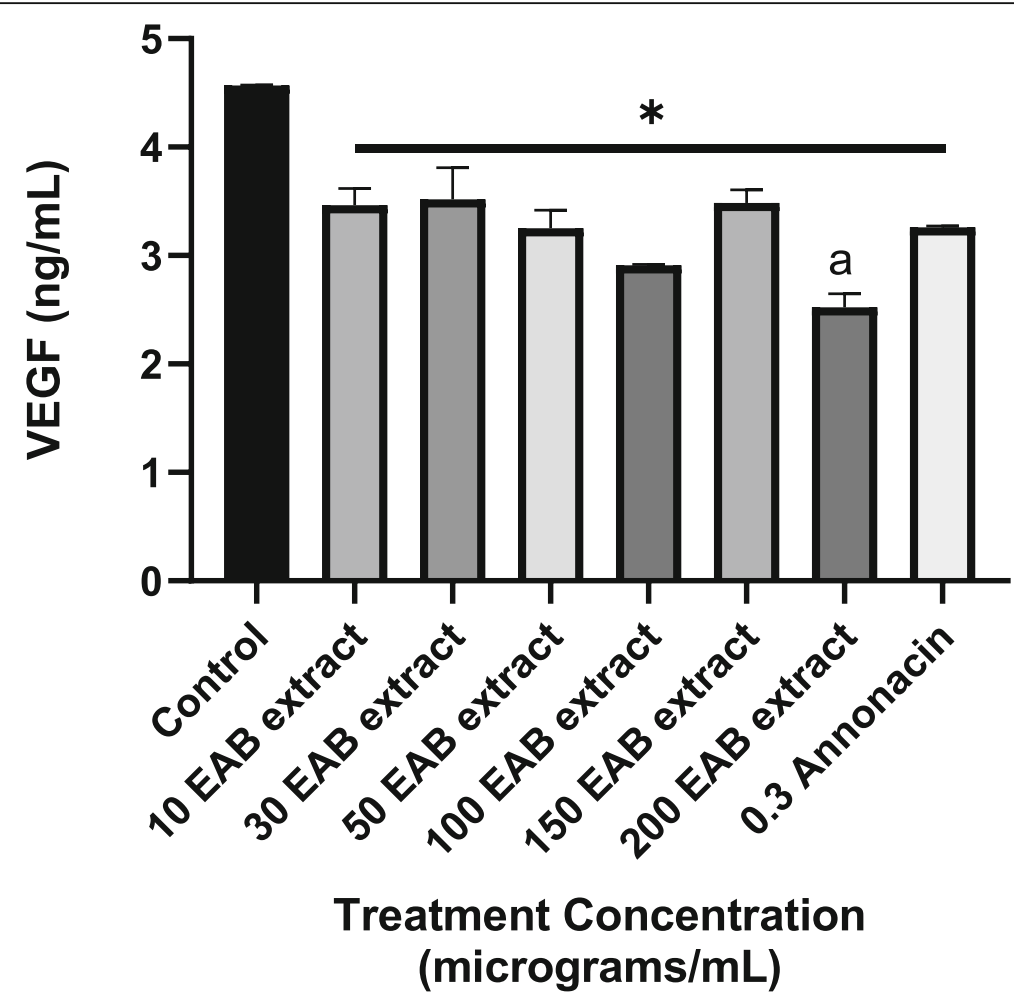

Fig. 11 VEGF levels are significantly decreased in the presence of EAB extract and annonacin. DU-145 cultured supernatants obtained after $72 \mathrm{~h}$ treatment with various concentrations of EAB extract and annonacin are displayed. . Results are expressed as means \pm SEM of triplicate values. * indicates statistically significant difference of all samples from corresponding control while ${ }^{a}$ denotes significance between the groups (one-way ANOVA, $P<0.05$ ) 
extract and phytochemical altered the cellular morphology of the cells, exhibiting typical necrotic characteristics with the absence of chromatin condensation. Although some forms of apoptosis cannot be totally ruled out. A. muricata has been shown to induce necrosis in pancreatic cancer cells via the inhibition of cellular metabolism [59], typical also of some other natural products [4]. Necrosis can occur via an organized process resulting from a signaling cascade involving RIP kinase which is then termed necroptosis as some of the biochemical markers of this process are similar to apoptosis [53, 60]. The cross talk between apoptosis and necroptosis involving numerous other pathways provides an opportunity for therapeutic development that can selectively target both or certain desired avenues [61]. Although apoptosis is the cell's preferred form of cell death, many tumors find effective ways for its evasion, leading to chemoresistance and tumor survival. Thus, therapies capable of activating non-apoptotic pathways potentially provide manipulation of cell deaths which would enhance their chemotherapeutic potential, should such resistance be developed. Whether or not the consumption of these natural products illicit an immune response as a result of resistance to apoptosis, and whether chronic inflammations is a result, are concerns worthy of future investigations using in-vivo models.

The EAB extract proved able to inhibit motility in the highly metastatic PC3 cell line preventing the wound healing process as demonstrated by the cell migration assay in Fig. 9, in addition to the significant inhibition of extracellular VEGF in Fig. 11. The EAB extract and annonacin also displayed potential in inhibiting the formation of new blood vessels in the CAM (Fig. 10). The ability of the tested extracts and annonacin to inhibit extracellular VEGF levels and blood vessel formation adduce to the probable potential of the samples to inhibit angiogenesis, one of the key mechanistic steps for tumor growth, invasion and metastasis in all cell types. Collectively, the results point to an interference in metastatic process, revealing potential of $A$. muricata in prostate cancer treatments.

\section{Conclusion}

The present study is the first demonstration (as far as the authors are aware) of selective, potent cytotoxic effects $A$. muricata bark extracts, against prostate cancer cell lines (PC3 and DU-145) in comparison with normal cells. Via a panel of in-vitro biochemical probes, the standardized ethyl acetate extract of the bark demonstrated a necrotic path of cell death without inciting reactive oxygen species, inhibiting markers of angiogenesis and enhanced the impact of the chemotherapy docetaxel on DU-145 cells. Taken together, these findings suggest the potential of annonacin and A. muricata bark extract as selective cytotoxic agents with antimetastatic, antiangiogenetic potential and warrants in-vivo investigations to determine physiological measures as well as a complete understanding of the mechanism(s) of the observed cytotoxicity.

\section{Abbreviations}

HPLC-MS: High-performance Liquid Chromatography - Mass Spectrometry; EAB: Ethyl acetate bark extract of Annona muricata; PC-3: Human prostate carcinoma cell line; DU-145: Human prostate carcinoma cell line; RWPE-

1: Human prostate normal epithelial cell line; ROS: Reactive oxygen species; DTS: Dibenzyl trisulfide; MTT: 3-(4,5-dimethylthiazol-2-yl)-2,5-

diphenyltetrazolium bromide; DMSO: Dimethyl sulfoxide; DCFDA: 2',7'dichlorofluorescein diacetate; $\mathrm{H}_{2} \mathrm{O}_{2}$ : Hydrogen peroxide; PBS: Phosphatebuffered saline; MMP: Mitochondrial membrane potential; AO/EB: Acridine orange/ethidium bromide; VEGF: Vascular endothelial growth factor;

CAM: Chorioallantoic membrane

\section{Acknowledgements}

We acknowledge the colleagues of the Pharmacology department, University of the Free State, South Africa and those at the Natural Products Institute, University of the West Indies for their assistance and helpful discussions in the anti-cancer mechanistic studies and cytotoxicity studies.

\section{Authors' contributions}

$\mathrm{RD}, \mathrm{KF}$ and MM conceived and designed the experiments. KF, SR, JE and OO performed the experiments and analyzed the data. JB, ML and AKS standardized the extract. KF and RD analyzed the data and wrote the manuscript. All authors read and approved the final manuscript. RD and MM raised funding support.

\section{Funding}

This work was supported by a grant from the National Commission of Science and Technology (Jamaica) and the National Research Fund (South Africa) via the Jamaica-South Africa joint scientific and technological cooperation; US National Cancer Institute and Caribbean Public Health Agency (CARPHA), the National Health Fund (Jamaica) and the University of the West Indies Development Fund (UWIDEF). The funders had no role in study design, data collection and analysis or preparation of the manuscript.

\section{Availability of data and materials}

The datasets used and analyzed during the current study are available from the corresponding author.

Ethics approval and consent to participate

Not applicable.

Consent for publication

Not applicable.

\section{Competing interests}

The authors declare that they have no competing interests.

\section{Author details}

${ }^{1}$ Natural Products Institute, University of the West Indies, Mona, Kingston 7, Jamaica. ${ }^{2}$ Biotechnolgy Centre, University of the West Indies, Mona, Kingston 7, Jamaica. ${ }^{3}$ Pharmacology Department, School of Clinical Medicine, Faculty of Health Sciences, University of the Free State, Bloemfontein, South Africa.

${ }^{4}$ School of Life Sciences, Pharmacy and Chemistry, Kingston University, Penrhyn Road, Kingston-upon-Thames, Surrey, UK. ${ }^{5}$ Jodrell Laboratory, Department of Natural Capital and Plant Health, Royal Botanic Gardens, Kew, Richmond TW9 3DS, UK. ${ }^{6}$ Faculty of Biological Sciences, University of Leeds, Leeds, England. 
Received: 19 June 2020 Accepted: 22 October 2020

Published online: 10 December 2020

\section{References}

1. Delgoda R, Murray JE. Evolutionary perspective on the role of plant secondary metabolites In: Badal S and Delgoda R, Editors. Pharmacognosy: fundamentals, applications and strategies. London: Elsevier Academic Press; 2016. p. 93-100.

2. Organization WH. WHO traditional medicine strategy 2002-2005. Geneva: World Health Organization; 2002

3. Picking D, Younger N, Mitchell S, Delgoda R. The prevalence of herbal medicine home use and concomitant use with pharmaceutical medicines in Jamaica. J Ethnopharmacol. 2011;137(1):305-11.

4. Newman DJ, Cragg GM. Natural products as sources of new drugs over the nearly four decades from 01/1981 to 09/2019. J Nat Prod. 2020;83(3):770803.

5. Rady I, Bloch MB, Chamcheu R-CN, Banang Mbeumi S, Anwar MR Mohamed H, Babatunde AS, Kuiate J-R, Noubissi FK, El Sayed KA. Anticancer properties of Graviola (Annona muricata): a comprehensive mechanistic review. Oxidative Med Cell Longev. 2018;2018:1-39. https://doi.org/10.1155/ 2018/1826170

6. Cragg, GM, Kingston DGl, Newman DJ, eds. Anticancer agents from natural products. Boca Raton: CRC press/Taylor \& Francis Group; 2011

7. Picking D, Delgoda R, Vandebroek I. Traditional knowledge systems and the role of traditional medicine in Jamaica. CAB Rev. 2019;14(045):1-13.

8. Williams LA, Rosner $H$, Kraus W. Molecules with potential for cancer therapy in the developing world: Dibenzyl trisulfide (DTS). In: Genomics Applications for the Developing World. New York, NY; Springer; 2012. p. 273-8.

9. Lowe H, Toyang N, Bryant J. In vitro and in vivo anti-cancer effects of Tillandsia recurvata (ball Moss) from Jamaica. West Indian Med J. 2013; 62(3):177-80

10. Campbell S, Murray J, Delgoda R, Gallimore W. Two new Oxodolastane Diterpenes from the Jamaican macroalga Canistrocarpus cervicornis. Mar Drugs. 2017;15(6):150.

11. Foster K, Younger N, Aiken W, Brady-West D, Delgoda R. Reliance on medicinal plant therapy among cancer patients in Jamaica. Cancer Causes Control. 2017:28(11):1349-56.

12. Fidianingsih I, Handayani ES. Annona muricata aqueous extract suppresses T47D breast cancer cell proliferation. Univ Med. 2015;33(1):19-26.

13. Clement $Y N$, Mahase $V$, Jagroop A, Kissoon K, Maharaj A, Mathura P, Mc Quan C, Ramadhin D, Mohammed C. Herbal remedies and functional foods used by cancer patients attending specialty oncology clinics in Trinidad. BMC Complement Altern Med. 2016;16(1):399.

14. Jacobo-Herrera NJ, Perez-Plasencia C, Castro-Torres VA, Martinez-Vazquez M, Gonzalez-Esquinca AR, Zentella-Dehesa A. The potential of acetogenins in cancer treatment. Front Pharmacol. 2019;10:783.

15. Coria-Téllez AV, Montalvo-Gónzalez E, Yahia EM, Obledo-Vázquez EN. Annona muricata: a comprehensive review on its traditional medicinal uses, phytochemicals, pharmacological activities, mechanisms of action and toxicity. Arab J Chem. 2018;11(5):662-91.

16. Atawodi SE. Nigerian foodstuffs with prostate cancer chemopreventive polyphenols. In: Infectious agents and cancer. BioMed Central. 2011;6(Suppl 2):S9. https://doi.org/10.1186/1750-9378-6-S2-S9.

17. Alonso-Castro AJ, Villarreal ML, Salazar-Olivo LA, Gomez-Sanchez M, Dominguez F, Garcia-Carranca A. Mexican medicinal plants used for cancer treatment: pharmacological, phytochemical and ethnobotanical studies. J Ethnopharmacol. 2011;133(3):945-72.

18. Monigatti M, Bussmann RW, Weckerle CS. Medicinal plant use in two Andean communities located at different altitudes in the Bolívar Province, Peru. J Ethnopharmacol. 2013;145(2):450-64.

19. Yang C, Gundala SR, Mukkavilli R, Vangala S, Reid MD, Aneja R. Synergistic interactions among flavonoids and acetogenins in Graviola (Annona muricata) leaves confer protection against prostate cancer. Carcinogenesis. 2015;36(6):656-65.

20. Fang XP, Rieser MJ, Gu ZM, Zhao GX, McLaughlin JL. Annonaceous acetogenins: an updated review. Phytochem Anal. 1993;4(1):27-48.

21. Al-Dabbagh B, Elhaty IA, Al Sakkaf R, El-Awady R, Ashraf SS, Amin A. Antioxidant and anticancer activities of Trigonella foenum-graecum, Cassia acutifolia and Rhazya stricta. BMC Complement Altern Med. 2018;18(1):1-12.

22. Lannuzel A, Michel P, Höglinger G, Champy P, Jousset A, Medja F, Lombes A, Darios F, Gleye C, Laurens A. The mitochondrial complex I inhibitor annonacin is toxic to mesencephalic dopaminergic neurons by impairment of energy metabolism. Neuroscience. 2003;121(2):287-96.

23. Yap CV, Subramaniam KS, Khor SW, Chung I. Annonacin exerts antitumor activity through induction of apoptosis and extracellular signal-regulated kinase inhibition. Pharm Res. 2017;9(4):378.

24. Yiallouris A, Patrikios I, Johnson EO, Sereti E, Dimas K, De Ford C, Fedosova NU, Graier WF, Sokratous K, Kyriakou K. Annonacin promotes selective cancer cell death via NKA-dependent and SERCA-dependent pathways. Cell Death Dis. 2018;9(7):764

25. Roduan MRM, Hamid RA, Mohtarrudin N. Modulation of cancer signalling pathway (s) in two-stage mouse skin tumorigenesis by annonacin. BMC Complement Altern Med. 2019;19(1):238.

26. Raybaudi-Massilia R, Suárez Al, Arvelo F, Sojo F, Mosqueda-Melgar J, Zambrano A, Calderón-Gabaldón MI. An analysis in-vitro of the cytotoxic, antioxidant and antimicrobial activity of aqueous and alcoholic extracts of Annona muricata L. seed and pulp. Br J Appl Sci Technol. 2015;5(4):333.

27. Sulistyoningrum E, Rachmani EPN, Baroroh HN, Rujito L. Annona muricata leaves extract reduce proliferative indexes and improve histological changes in rat's breast cancer. J Appl Pharm Sci. 2017;7(01):149-55.

28. Moghadamtousi SZ, Karimian H, Rouhollahi E, Paydar M, Fadaeinasab M, Kadir HA. Annona muricata leaves induce G1 cell cycle arrest and apoptosis through mitochondria-mediated pathway in human HCT-116 and HT-29 colon cancer cells. J Ethnopharmacol. 2014;156:277-89.

29. Moghadamtousi SZ, Rouhollahi E, Karimian H, Fadaeinasab M, Firoozinia M, Abdulla MA, Kadir HA. The chemopotential effect of Annona muricata leaves against azoxymethane-induced colonic aberrant crypt foci in rats and the apoptotic effect of acetogenin annomuricin E in HT-29 cells: a bioassayguided approach. PLoS One. 2015;10(4):e0122288.

30. Yuan S-SF, Chang H-L, Chen H-W, Yeh Y-T, Kao Y-H, Lin K-H, Wu Y-C, Su J-H. Annonacin, a mono-tetrahydrofuran acetogenin, arrests cancer cells at the G1 phase and causes cytotoxicity in a Bax-and caspase-3-related pathway. Life Sci. 2003;72(25):2853-61.

31. Supino R. MTT assays. In: O'Hare S, Atterwill CK. (eds) In Vitro Toxicity Testing Protocols. Methods in Molecular Biology ${ }^{\mathrm{TM}}$, vol 43. Humana Press; 1995. p.137-49.

32. Van Meerloo J, Kaspers GJ, Cloos J. Cell sensitivity assays: the MTT assay. In: Cancer cell culture, Humana Press; 2011. p. 237-45.

33. Koch H, Woodward J, Langat MK, Brown MJ, Stevenson PC. Flagellum removal by a nectar metabolite inhibits infectivity of a bumblebee parasite. Curr Biol. 2019;29(20):3494-500 e3495.

34. Simon H-U, Haj-Yehia A, Levi-Schaffer F. Role of reactive oxygen species (ROS) in apoptosis induction. Apoptosis. 2000;5(5):415-8.

35. Pieme CA, Kumar SG, Dongmo MS, Moukette BM, Boyoum FF, Ngogang JY, Saxena AK. Antiproliferative activity and induction of apoptosis by Annona muricata (Annonaceae) extract on human cancer cells. BMC Complement Altern Med. 2014;14(1):516

36. Bock FJ, Tait SW. Mitochondria as multifaceted regulators of cell death. Nat Rev Mol Cell Biol. 2020;21(2):85-100.

37. Sirenko O, Hesley J, Rusyn I, Cromwell EF. High-content assays for hepatotoxicity using induced pluripotent stem cell-derived cells. Assay Drug Dev Technol. 2014;12(1):43-54.

38. Lu C, Hassan H. Human stem cell factor-antibody [anti-SCF] enhances chemotherapy cytotoxicity in human CD34+ resistant myeloid leukaemia cells. Leuk Res. 2006;30(3):296-302.

39. Huang T-C, Lee J-F, Chen J-Y. Pardaxin, an antimicrobial peptide, triggers caspase-dependent and ROS-mediated apoptosis in HT-1080 cells. Marine drugs. 2011;9(10):1995-2009.

40. Mahajan SD, Tutino VM, Redae Y, Meng H, Siddiqui A, Woodruff TM, Jarvis JN, Hennon T, Schwartz S, Quigg RJ. C5a induces caspase-dependent apoptosis in brain vascular endothelial cells in experimental lupus. Immunology. 2016;148(4):407-19.

41. Liu K, Liu P-C, Liu R, Wu X. Dual AO/EB staining to detect apoptosis in osteosarcoma cells compared with flow cytometry. Med Sci Monit Basic Res. 2015;21:15.

42. Wang H, Liu W, Black S, Turner O, Daniel JM, Dean-Colomb W, He QP, Davis $M$, Yates $C$. Kaiso, a transcriptional repressor, promotes cell migration and invasion of prostate cancer cells through regulation of miR-31 expression. Oncotarget. 2016;7(5):5677

43. Bala A, Mukherjee P, Braga F, Matsabisa M. Comparative inhibition of MCF-7 breast cancer cell growth, invasion and angiogenesis by Cannabis sativa L. sourced from sixteen different geographic locations. S Afr J Bot. 2018:119. $154-62$. 
44. Yang Z, Lu W, Ma X, Song D. Bioassay-guided isolation of an alkaloid with antiangiogenic and antitumor activities from the extract of Fissistigma cavaleriei root. Phytomedicine. 2012;19(3-4):301-5.

45. Guo J, Zhu T, Chen L, Nishioka T, Tsuji T, Xiao Z-XJ, Chen CY. Differential sensitization of different prostate cancer cells to apoptosis. Genes Cancer. 2010;1(8):836-46.

46. Jayakumar S, Kunwar A, Sandur SK, Pandey BN, Chaubey RC. Differential response of DU145 and PC3 prostate cancer cells to ionizing radiation: role of reactive oxygen species, GSH and Nrf2 in radiosensitivity. Biochim Biophys Acta. 2014;1840(1):485-94.

47. Karanika S, Karantanos T, Kurosaka S, Wang J, Hirayama T, Yang G, Park S, Golstov AA, Tanimoto R, Li L. GLIPR1- $\Delta$ TM synergizes with docetaxel in cell death and suppresses resistance to docetaxel in prostate cancer cells. Mol Cancer. 2015;14(1):122.

48. Xiang J, Wan C, Guo R, Guo D. Is hydrogen peroxide a suitable apoptosis inducer for all cell types? Biomed Res Int. 2016;2016:1-6. https://doi.org/10 1155/2016/7343965.

49. Ribble D, Goldstein NB, Norris DA, Shellman YG. A simple technique for quantifying apoptosis in 96-well plates. BMC Biotechnol. 2005;5(1):12.

50. Alfano ACC, Paiva CE, Rugno FC, da Silva RH, Paiva BSR. Biologically based therapies are commonly self-prescribed by Brazilian women for the treatment of advanced breast cancer or its symptoms. Support Care Cancer. 2014;22(5):1303-11.

51. Almog L, Lev E, Schiff E, Linn S, Ben-Arye E. Bridging cross-cultural gaps: monitoring herbal use during chemotherapy in patients referred to integrative medicine consultation in Israel. Support Care Cancer. 2014; 22(10):2793-804

52. Alsanad SM, Howard RL, Williamson EM. An assessment of the impact of herb-drug combinations used by cancer patients. BMC Complement Altern Med. 2016;16(1):393.

53. Green DR, Kroemer G. The pathophysiology of mitochondrial cell death. Science. 2004;305(5684):626-9.

54. Redza-Dutordoir M, Averill-Bates DA. Activation of apoptosis signalling pathways by reactive oxygen species. Biochim Biophys Acta. 2016;1863(12): 2977-92.

55. Jäättelä M. Multiple cell death pathways as regulators of tumour initiation and progression. Oncogene. 2004;23(16):2746-56.

56. Laksmitawati DR, Prasanti AP, Larasinta N, Syauta GA, Hilda R, Ramadaniati HU, Widyastuti A, Karami N, Afni M, Rihibiha DD. Anti-inflammatory potential of gandarusa (Gendarussa vulgaris Nees) and soursoup (Annona muricata L) extracts in LPS stimulated-macrophage cell (RAW264. 7). J Nat Remedies. 2016;16(2):73-81.

57. Krysko O, De Ridder L, Cornelissen M. Phosphatidylserine exposure during early primary necrosis (oncosis) in JB6 cells as evidenced by immunogold labeling technique. Apoptosis. 2004;9(4):495-500.

58. Kögel D, Prehn JH. Caspase-independent cell death mechanisms. In: Madame Curie Bioscience Database [Internet]. Austin (TX): Landes Bioscience; 2013. Available from: https:/www.ncbinlm.nih.gov/books/NBK6197/.

59. Torres MP, Rachagani S, Purohit V, Pandey P, Joshi S, Moore ED, Johansson SL, Singh PK, Ganti AK, Batra SK. Graviola: a novel promising natural-derived drug that inhibits tumorigenicity and metastasis of pancreatic cancer cells in vitro and in vivo through altering cell metabolism. Cancer Lett. 2012; 323(1):29-40.

60. Berghe TV, Grootjans S, Goossens V, Dondelinger Y, Krysko DV, Takahashi N, Vandenabeele P. Determination of apoptotic and necrotic cell death in vitro and in vivo. Methods. 2013;61(2):117-29.

61. Lamb HM. Double agents of cell death: novel emerging functions of apoptotic regulators. FEBS J. 2020;287(13):2647-63.

\section{Publisher's Note}

Springer Nature remains neutral with regard to jurisdictional claims in published maps and institutional affiliations.

Ready to submit your research? Choose BMC and benefit from:

- fast, convenient online submission

- thorough peer review by experienced researchers in your field

- rapid publication on acceptance

- support for research data, including large and complex data types

- gold Open Access which fosters wider collaboration and increased citations

- maximum visibility for your research: over $100 \mathrm{M}$ website views per year

At BMC, research is always in progress.

Learn more biomedcentral.com/submissions 